\title{
Drug-drug interactions in inpatient and outpatient settings in Iran: a systematic review of the literature
}

\author{
Ehsan Nabovati ${ }^{1,2}$, Hasan Vakili-Arki ${ }^{1}$, Zhila Taherzadeh ${ }^{3,4}$, Mohammad Reza Hasibian ${ }^{6}$, Ameen Abu-Hanna ${ }^{7}$
} and Saeid Eslami ${ }^{5,6,7^{*}}$

\begin{abstract}
Drug-drug interactions (DDIs) are an important type of adverse drug events. Yet overall incidence and pattern of DDIs in Iran has not been well documented and little information is available about the strategies that have been used for their prevention. The purpose of this study was to systematically review the literature on the incidence and pattern of DDIs in Iran as well as the used strategies for their prevention. PubMed, Scopus, electronic Persian databases, and Google Scholar were searched to identify published studies on DDIs in Iran. Additionally, the reference lists of all retrieved articles were reviewed to identify additional relevant articles. Eligible studies were those that analyzed original data on the incidence of DDIs in inpatient or outpatient settings in Iran. Articles about one specific DDI and drug interactions with herbs, diseases, and nutrients were excluded. The quality of included studies was assessed using quality assessment criteria. Database searches yielded 1053 potentially eligible citations. After removing duplicates, screening titles and abstracts, and reading full texts, 34 articles were found to be relevant. The quality assessment of the included studies showed a relatively poor quality. In terms of study setting, 18 and 16 studies have been conducted in inpatient and outpatient settings, respectively. All studies focused on potential DDIs while no study assessed actual DDls. The median incidence of potential DDIs in outpatient settings was $8.5 \%$ per prescription while it was $19.2 \%$ in inpatient settings. The most indicated factor influencing DDIs incidence was patient age. The most involved drug classes in DDls were beta blockers, angiotensin-converting-enzyme inhibitors (ACEls), diuretic agents, and non-steroidal anti-inflammatory drugs (NSAIDs). Thirty-one studies were observational and three were experimental in which the strategies to reduce DDls were applied. Although almost all studies concluded that the incidence of potential DDIs in Iran in both inpatient and outpatient settings was relatively high, there is still no evidence of the incidence of actual DDls. More extensive research is needed to identify and minimize factors associated with incidence of DDIs, and to evaluate the effects of preventive interventions especially those that utilize information technology.
\end{abstract}

Keywords: Adverse drug events, Developing countries, Drug-drug interaction, Medication errors, Incidence, Intervention, Iran

\footnotetext{
* Correspondence: EslamiS@mums.ac.ir

${ }^{5}$ Pharmaceutical Research Center, School of Pharmacy, Mashhad University of Medical Sciences, Mashhad, Iran

${ }^{6}$ Department of Medical Informatics, Faculty of Medicine, Mashhad University of Medical Sciences, Mashhad, Iran

Full list of author information is available at the end of the article
}

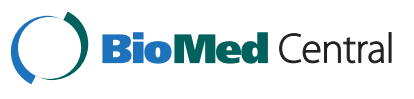

(c) 2014 Nabovati et al.; licensee BioMed Central Ltd. This is an Open Access article distributed under the terms of the Creative Commons Attribution License (http://creativecommons.org/licenses/by/4.0), which permits unrestricted use, distribution, and reproduction in any medium, provided the original work is properly credited. The Creative Commons Public Domain Dedication waiver (http://creativecommons.org/publicdomain/zero/1.0/) applies to the data made available in this article, unless otherwise stated. 


\section{Introduction}

Adverse drug events (ADE) are the most common complications related to medication therapy among patients [1-3]. ADEs are common, costly, and may have life-threatening consequences [4-6]. The high incidence of medication use in medical therapy and possibility of human errors increase the incidence risk of these adverse events.

Drug-drug interactions (DDIs) are an important subgroup of ADEs [7] which are highly prevalent in patients receiving multiple-drug treatment [8]. DDIs may lead to severe adverse events which can result in patient hospitalization. Some studies have estimated that up to $3 \%$ of hospital admissions are caused by DDIs [9-11].

Although it is widely recognized that DDIs may harm patients, their incidence is still high [12]. The majority of these interactions occurred because either prescribers do not consider them relevant [13] or prescribers' knowledge of DDIs is generally poor [14]. Hence, they could be prevented through applying proper interventions. This can improve the quality of drug therapy and increase patient safety. Interventions aimed at reducing DDIs are likely to be more effective, if before their development, the incidence and pattern of DDIs are determined accurately.

Estimates about the incidence of DDIs in different countries vary from $6 \%$ to $70 \%$ due to variability in methodologies and settings [12,15-18]. Because of this variation, it is important that the related evidence is aggregated and summarized in each country, separately. To our knowledge, three systematic reviews in the literature reviewed DDIs studies. Espinosa-Bosch et al. conducted a review on English and Spanish studies which had reported incidence of DDIs in hospital care [19]. They showed that around $20 \%$ of hospitalized patients were susceptible to DDIs and incidence was higher in patients with heart disease and the elderly. Another review has summarized and described findings from studies that assessed harmful DDIs in elderly patients [20]. It has been conclusively shown that significant harm is associated with DDIs in elderly patients. Also, Riechelmann and Giglio systematically reviewed the studies, published in English, Portuguese, and Spanish, on the frequency of DDIs in cancer patients [21]. They estimated that about one-third of cancer patients are at the risk of DDIs.

None of the DDIs systematic reviews were conducted in a developing country. In Iran, several DDIs studies have been conducted, but there is uncertainty about their overall incidence, pattern of the most involved medication classes, and the possible interventions and their effectiveness.

The objective of this systematic review is to identify and summarize all evidence concerning DDIs in Iran as an example of a developing country. In this study we address four questions: (1) what is the incidence and pattern of DDIs?; (2) which factors are associated to incidence of
DDIs?; (3) what interventions have been used to prevent this type of medication errors?; (4) which interventions have been effective in reducing DDIs?

\section{Methods}

\section{Search strategy and data sources}

A comprehensive search strategy for original articles was developed using terms related to drug interaction (drug interaction, adverse drug event, adverse drug reaction, medication error, prescription error) combined with terms related to Iran (Iran, Iranian).

The following electronic databases were searched for English articles using customized search strategies: MEDLINE/PubMed and Scopus. Persian Electronic databases including Scientific Information Database (SID), IranMedex, IranDoc, and MagIran were searched using Persian terms equivalent to the English terms mentioned above. The electronic databases were last searched on March 2013. To ensure that no article is missed, we also searched Google Scholar using both Persian and English search terms.

In a final search, the reference lists of all identified articles were also reviewed to identify additional relevant articles (snowball method).

\section{Inclusion and exclusion criteria}

All published studies on children, adults, and elderly patients that were conducted in either an outpatient or inpatient setting in Iran and published either in English or Persian were included. Various types of research designs including observational studies that reported the incidence of DDIs and interventional studies that evaluated an intervention on reduction of DDIs were included.

Articles about one specific DDI and drug interactions with herbs, diseases, and nutrients were excluded. Moreover, we excluded letters, opinions, conference papers, and dissertations.

\section{Review procedure and data extraction}

A reviewer conducted the search for the articles. Two reviewers (including the one conducting the literature search) considered the inclusion and exclusion criteria independently and screened the title and abstract of all potential relevant articles. Any discrepancies on the eligibility of the articles were resolved by discussion among the reviewers. After the inclusion process, the full text of eligible articles for the purposes of this review was retrieved. In the case of inaccessibility, the full text was requested from the authors by email. The full text of each eligible article was reviewed and abstracted into a prespecified form.

The data abstraction form was used to collect information on the following characteristics: objectives, setting, study period, type of study, sampling, data source, DDIs reference, main findings, details of reported DDIs, 
most frequent DDIs, factors associated with incidence of DDIs, interventions and their outcomes, and other relevant information.

\section{Quality assessment of the included studies}

There is no tool that assesses the quality of DDIs studies. A twelve-item quality assessment tool (Table 1) was developed based on the criteria taken from the tools for assessing the quality of medication error studies [22,23]. Overall quality scores ranged from 0 to 12 ( 0 to 6 points $=$ poor, 7 to 9 points $=$ moderate, 10 to 12 points $=$ high). Two reviewers independently scored the quality criteria for each included study and a third reviewer resolved any discrepancies.

Due to variations in the methods used to report on DDI statistics, we mainly reported qualitative aggregate results.

\section{Results}

\section{Literature search results}

The flow diagram of literature search is shown in Figure 1. Electronic literature search on MEDLINE/PubMed, Scopus and Persian databases identified a total of 1053 records. 861 unique records remained after excluding duplicates. After reviewing titles and abstracts and applying inclusion and exclusion criteria, 54 articles were chosen for full text review. By hand-searching the references list, two additional relevant articles were also identified. Subsequently, the full texts of these potentially relevant articles were obtained except one [24] (even after contacting its authors by email). After detailed full text review of 55 articles, a further 21 articles were excluded, because they only assessed pattern of drug prescribing, only evaluated

Table 1 The tool used to rate the quality of the included studies

\begin{tabular}{ll}
\hline Quality assessment criteria & Score \\
\hline 1) Aims/objectives of the study clearly stated & 1 \\
2) Definition of what constitutes a DDI & 1 \\
3) DDI categories specified & 1 \\
4) DDI categories defined & 1 \\
5) Mention of DDI reference & 1 \\
6) Data collection method described clearly & 1 \\
7) Setting in which study was conducted described & 1 \\
8) Study subjects described & 1 \\
9) Sampling and calculation of sample size described & 1 \\
(unit of measurement) & 1 \\
10) Potential or actual DDls assessed & 1 \\
11) Measures in place to ensure that results are valid & 1 \\
12) Limitations of study listed & 12 points \\
Maximum score & 1
\end{tabular}

Each item is related to a quality assessment criterion with score 0 or 1 . quality of drug prescribing, or only estimated prescription errors without referring to DDIs. Finally, 34 relevant articles that met our specified criteria were included in this review.

\section{General characteristics of the included studies}

The oldest study was published in 1997 and the most recent one in 2013. Twenty-one studies (62\%) had been written in Persian and 13 (38\%) were in English. In terms of study setting, 15 (44\%) and 19 (56\%) studies have been conducted in inpatient and outpatient settings, respectively. In terms of study design, 31 studies (91\%) were observational and three (9\%) were experimental. The majority of studies, 20 out of 34, had used Drug Interaction Facts as their DDI compendia. Table 2 shows the general characteristics of the included studies.

\section{Quality of the included studies}

After the quality assessment of individual studies, none of them fulfilled all the quality criteria. Three studies (9\%) were of higher quality (10 points), 16 studies (47\%) were of moderate quality ( 7 to 9 points), and 15 studies (44\%) were of poor quality ( 0 to 6 points). In terms of the quality assessment criteria, no study assessed actual DDIs, only four studies (12\%) listed their limitations, and 15 studies (44\%) defined DDIs categories.

\section{Findings of the included studies}

Twenty-five (73.5\%) studies reported the overall incidence of potential DDIs in the study population (prescription or patient). Nine studies (26.5\%) have not reported the overall incidence of DDIs. Among the studies performed in outpatient settings, nine studies assessed the overall incidence of potential DDIs in prescriptions in the population for all types of drugs. The median incidence of potential DDIs in prescriptions of these studies was 8.5\% (Interquartile Range (IQR): 8.4-10.1). The other outpatient studies focused on the incidence of potential DDIs in cardiovascular drugs (DDIs percentage $=50 \%$ ) [26], non-steroidal anti-inflammatory drugs (NSAIDs) (DDIs percentage $=49 \%$ ) [30], antidepressant drugs (DDIs percentage $=22 \%$ ) [29], dental drugs (DDIs percentage $=27 \%$ ) [39], and elderly people (DDIs percentage $=10 \%$ and 14\%) $[47,51]$.

Among the studies performed on inpatient prescriptions, four assessed the overall incidence of potential DDIs in prescriptions for all groups of patients in all departments and for all drug classes [24,25,52,53]. The median incidence of potential DDIs in these studies was 19.2\% (IQR: 15.5-22). The focus of one study in inpatient setting was on pediatric patients (DDIs percentage $=21 \%$ ) [37] . The two studies that focused on potential DDIs in hospitalized patients in the hematology and oncology departments reported the incidence of $38 \%$ and $63 \%$ [55,57]. 


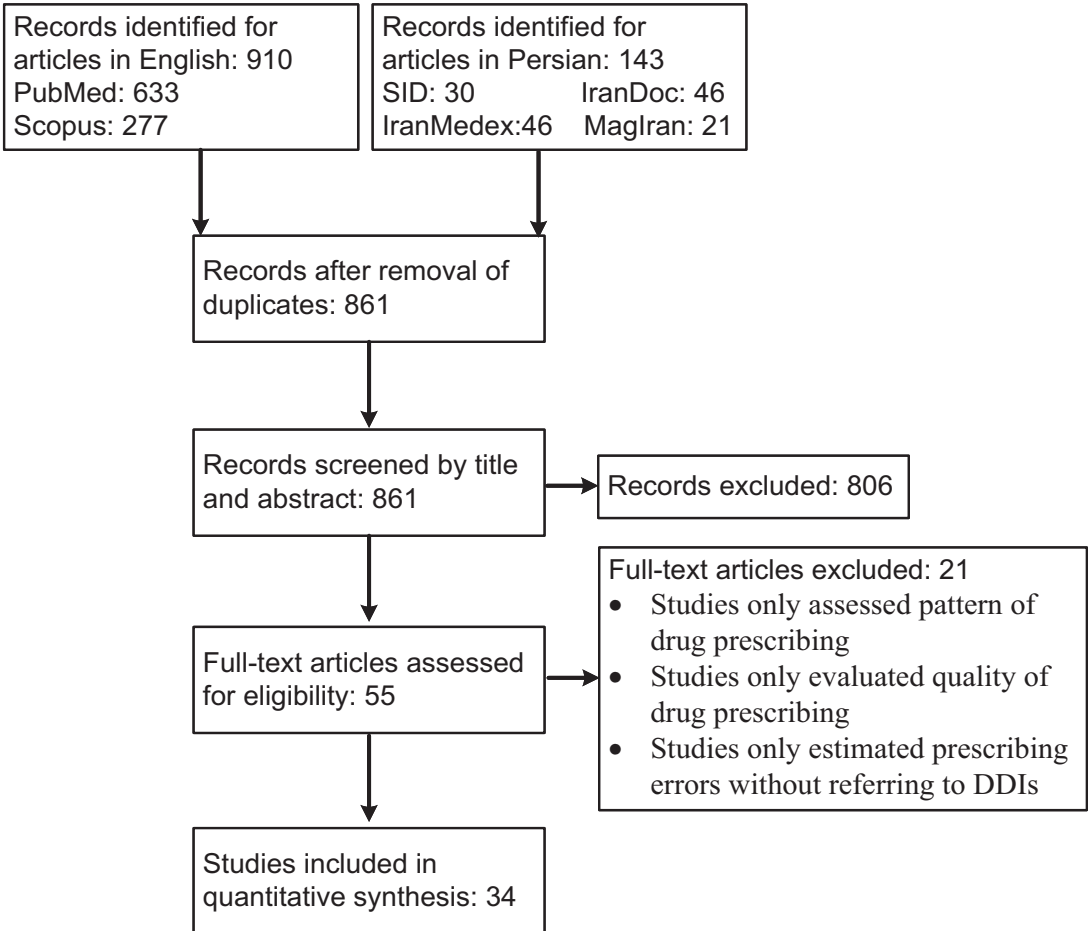

Figure 1 Flow diagram of the literature search and study selection. The search strategy focused on studies that analyzed original data on the incidence of DDls in inpatient or outpatient settings in Iran.

More than half of the studies (21 studies, amounting to $62 \%$ ) have grouped the identified DDIs in terms of severity and reported the percentage of major, moderate, and minor DDIs separately. The median percentage of major, moderate, and minor DDIs in these studies were 7.7\% (IQR: 4.4-11.6), 67.4\% (IQR: 51.3-75.3), and 24.2\% (IQR: 16.4-41.9), respectively. Six additional studies (17.5\%) have calculated the percentage of prescriptions with at least one DDI grouped by severity. The median percentage of prescriptions with major, moderate, and minor DDIs were 0.8\% (IQR: 0.7-1.3), 10.2\% (IQR: 5.6-11.2), and 9.6\% (IQR: 3.6-22.8), respectively.

Fifteen studies (44\%) have confirmed the association between the number of medications and the incidence of DDIs. The influence of other factors on incidence of DDIs was mentioned in 11 studies (32\%). These factors are listed in Table 3.

Twenty three studies $(67.6 \%)$ have determined the most frequent DDIs. Among them, eight studies have also classified the most frequent DDIs by severity. The most frequent major DDIs in the studies, which ranked in the first 10 identified DDIs, are listed in Table 4. As this table shows, five studies have ranked the major interaction between digoxin and furosemide among the most frequent interactions.

Names and classes of drugs which mostly contributed to DDIs have been reported by 14 studies (Table 5 ).
Beta blockers, angiotensin-converting-enzyme inhibitors (ACEIs), diuretic agents, and NSAIDs have been mentioned most often as drug classes. Digoxin contributed the most to major DDIs.

\section{Interventional studies}

Among the included studies, only three were interventional. All three were quasi experimental and have been conducted in outpatient settings. In the first study [34], the effects of face to face education, information feedback, and pamphlets designation were evaluated. The study shown that potential DDIs in general practitioners and specialists' prescriptions decreased (severe: $1.6 \%$ before vs. $0.24 \%$ after, moderate: $10.6 \%$ before vs. $2 \%$ after, minor: $5.1 \%$ before vs. $2.1 \%$ after, $\mathrm{p}$-value $<0.001)$. In the second study [35], individualized feedback and workshop training programs were used. The study mentioned that potential DDIs with first significance degree (based on Drug Interactions Facts ${ }^{\mathrm{Tx}}$ ) in general practitioners' prescriptions reduced significantly ( $0.4 \%$ before vs. $0.05 \%$ after interventions, $\mathrm{p}$-value $<0.001)$. The third study [46] evaluated the effect of face-to-face training, audit feedback, and educational notes on the major DDIs in general practitioners and specialists' prescriptions. It demonstrated that severe DDIs diminished significantly $(1.5 \%$ before vs. $0.4 \%$ after, p-value $<0.05)$. 
Table 2 General characteristics of the included studies

\begin{tabular}{|c|c|c|c|c|c|c|c|c|c|}
\hline Ref & Year & Language & $\begin{array}{l}\text { Target } \\
\text { population }\end{array}$ & Setting & $\begin{array}{l}\text { Pathology/Drug } \\
\text { type }\end{array}$ & Design & Duration & $\begin{array}{l}\text { Sample Size/Unit } \\
\text { of Analysis }\end{array}$ & Drug interaction database \\
\hline [24] & 1997 & Persian & All & Outpatient & All & $\begin{array}{l}\text { Observational } \\
\text { (Retrospective) }\end{array}$ & 2 months & 3117 Prescriptions & - \\
\hline [25] & 1997 & Persian & All & $\begin{array}{l}\text { Inpatient } \\
\text { (Internal, Surgery) }\end{array}$ & All & $\begin{array}{l}\text { Observational } \\
\text { (Retrospective) }\end{array}$ & 3 months & 1000 Prescriptions & - \\
\hline [26] & 1999 & Persian & All & Outpatient & $\begin{array}{l}\text { Cardiovascular } \\
\text { drugs }\end{array}$ & $\begin{array}{l}\text { Observational } \\
\text { (Retrospective) }\end{array}$ & 6 months & 1038 Prescriptions & Drug Interaction Facts \\
\hline [27] & 2000 & Persian & All & Outpatient & All & $\begin{array}{l}\text { Observational } \\
\text { (Retrospective) }\end{array}$ & 12 Months & 4750 Prescriptions & Drug Interaction Facts \\
\hline [28] & 2001 & Persian & All & Outpatient & All & $\begin{array}{l}\text { Observational } \\
\text { (Retrospective) }\end{array}$ & 3 months & 1100 Prescriptions & Drug Interaction Facts \\
\hline [29] & 2000 & Persian & All & Outpatient & $\begin{array}{l}\text { Anti-Depression } \\
\text { drugs }\end{array}$ & $\begin{array}{l}\text { Observational } \\
\text { (Retrospective) }\end{array}$ & 6 months & 3000 Prescriptions & Drug Interaction Facts \\
\hline [30] & 1999-2001 & Persian & All & Outpatient & NSAID & $\begin{array}{l}\text { Observational } \\
\text { (Retrospective) }\end{array}$ & 36 months & 1927 Prescriptions & Hansten Drug Interactions \\
\hline [31] & 2000 & Persian & All & Outpatient & All & $\begin{array}{l}\text { Observational } \\
\text { (Retrospective) }\end{array}$ & 6 months & 3000 Prescriptions & Drug Interaction Facts \\
\hline [32] & 2000 & Persian & All & Outpatient & All & $\begin{array}{l}\text { Observational } \\
\text { (Retrospective) }\end{array}$ & 12 months & 1800 Prescriptions & Drug Interaction Facts \\
\hline [33] & 2001 & Persian & All & Outpatient & All & $\begin{array}{l}\text { Observational } \\
\text { (Retrospective) }\end{array}$ & 6 months & 5300 Prescriptions & Drug Interaction Facts \\
\hline [34] & 2005-2006 & Persian & All & Outpatient & All & $\begin{array}{l}\text { Interventional } \\
\text { (Quasi Experimental) }\end{array}$ & 6 months & $\begin{array}{l}5300 \text { Prescriptions - } \\
43 \text { Prescribers }\end{array}$ & Drug Interaction Facts \\
\hline [35] & $2002-2003$ & Persian & All & Outpatient & All & $\begin{array}{l}\text { Interventional } \\
\text { (Quasi Experimental) }\end{array}$ & 12 months & $\begin{array}{l}6704 \text { Prescriptions - } \\
119 \text { Prescribers }\end{array}$ & Drug Interaction Facts \\
\hline [36] & 2006 & Persian & All & Inpatient & All & $\begin{array}{l}\text { Observational } \\
\text { (Retrospective) }\end{array}$ & 1 month & 6969 Prescriptions & - \\
\hline [37] & 2004 & Persian & Pediatrics & Inpatient & All & $\begin{array}{l}\text { Observational } \\
\text { (Retrospective) }\end{array}$ & 6 months & 898 Medical Records & Drug Interaction Facts \\
\hline [38] & 2008 & Persian & All & Outpatient & All & $\begin{array}{l}\text { Observational } \\
\text { (Retrospective) }\end{array}$ & 6 months & 167305 Prescriptions & - \\
\hline [39] & $2005-2006$ & Persian & All & Outpatient & Dental & $\begin{array}{l}\text { Observational } \\
\text { (Retrospective) }\end{array}$ & 6 months & 666 Prescriptions & - \\
\hline [40] & 2009 & Persian & $\begin{array}{l}\text { war-injured } \\
\text { veterans } \\
\text { with Psychiatric } \\
\text { disorders }\end{array}$ & Outpatient & All & $\begin{array}{l}\text { Observational } \\
\text { (Retrospective) }\end{array}$ & 3 months & 150 Patients & $\begin{array}{l}\text { Food and Drug } \\
\text { Administration Package }\end{array}$ \\
\hline [41] & $2006-2007$ & Persian & All & Inpatient & All & $\begin{array}{l}\text { Observational } \\
\text { (Retrospective) }\end{array}$ & 6 months & 400 Medical Records & Hansten Drug Interactions \\
\hline
\end{tabular}


Table 2 General characteristics of the included studies (Continued)

\begin{tabular}{|c|c|c|c|c|c|c|c|c|c|}
\hline$[42]$ & $2009-2010$ & Persian & All & Inpatient (ICU) & All & $\begin{array}{l}\text { Observational } \\
\text { (Retrospective) }\end{array}$ & 12 months & 371 Medical Records & Drug Interaction Facts \\
\hline [43] & 2010 & Persian & $\begin{array}{l}\text { war-injured } \\
\text { veterans } \\
\text { with Psychiatric } \\
\text { disorders }\end{array}$ & Inpatient & All & $\begin{array}{l}\text { Observational } \\
\text { (Retrospective) }\end{array}$ & 4 months & 1435 Patients & $\begin{array}{l}\text { Food and Drug Administration } \\
\text { Package }\end{array}$ \\
\hline$[44]$ & 2009 & Persian & Elderly & Inpatient (ICU) & All & $\begin{array}{l}\text { Observational } \\
\text { (Retrospective) }\end{array}$ & 12 months & 70 Patients & Drug Interaction Facts \\
\hline [45] & 2000 & English & All & $\begin{array}{l}\text { Inpatient (ICU, } \\
\mathrm{CCU} \text {, internal and } \\
\text { infectious) }\end{array}$ & All & $\begin{array}{l}\text { Observational } \\
\text { (Retrospective) }\end{array}$ & 6 months & 3130 Prescriptions & Drug Interaction Facts \\
\hline [46] & 2002 & English & All & Outpatient & All & $\begin{array}{l}\text { Interventional } \\
\text { (Quasi Experimental) }\end{array}$ & 6 months & 5600 Prescriptions & Drug Interaction Facts \\
\hline$[47]$ & 2000 & English & Elderly & Outpatient & All & $\begin{array}{l}\text { Observational } \\
\text { (Retrospective) }\end{array}$ & 2 months & 3000 Prescriptions & Drug-Reax (Micromedex) \\
\hline [48] & 2005 & English & All & Inpatient (ICU) & All & $\begin{array}{l}\text { Observational } \\
\text { (Retrospective) }\end{array}$ & 6 months & 567 prescriptions & Drug Interaction Facts \\
\hline [49] & $2006-2008$ & English & All & Outpatient & All & $\begin{array}{l}\text { Observational } \\
\text { (Retrospective) }\end{array}$ & 24 months & $11,562,808$ prescriptions & Drug Interaction Facts \\
\hline$[50]$ & $2007-2009$ & English & All & Outpatient & All & $\begin{array}{l}\text { Observational } \\
\text { (Retrospective) }\end{array}$ & 30 months & 44,567,750 Prescriptions & Drug Interaction Facts \\
\hline [51] & $2005-2006$ & English & Elderly & Outpatient & All & $\begin{array}{l}\text { Observational } \\
\text { (Retrospective) }\end{array}$ & 12 months & 2041 Patients & Swedish Classification System \\
\hline [52] & 2001 & English & All & Inpatient & All & $\begin{array}{l}\text { Observational } \\
\text { (Prospective) }\end{array}$ & 3 months & 519 Prescriptions & Drug Interaction Facts \\
\hline [53] & 2010 & English & Adults & Inpatient & All & $\begin{array}{l}\text { Observational } \\
\text { (Retrospective) }\end{array}$ & 12 months & 1000 Prescriptions & $\begin{array}{l}\text { A computerized DDI database } \\
\text { system (Prescription Analyzer } \\
\text { 2000, Sara Rayane Co., Iran) }\end{array}$ \\
\hline [54] & 2012 & English & All & Inpatient (ICU) & All & $\begin{array}{l}\text { Observational } \\
\text { (Prospective) }\end{array}$ & 20 days & 101 patients & Drug Interaction Facts \\
\hline [55] & $2011-2012$ & English & All & $\begin{array}{l}\text { Inpatient } \\
\text { (hematology- } \\
\text { oncology ward) }\end{array}$ & $\begin{array}{l}\text { Cancer Patients/Anti- } \\
\text { Cancer and Non-Anti- } \\
\text { Cancer drugs }\end{array}$ & $\begin{array}{l}\text { Observational } \\
\text { (Prospective) }\end{array}$ & 6 months & 83 patients & On-Desktop Lexi-Interact \\
\hline [56] & 2011 & English & All & Inpatient (Post-ICU) & All & $\begin{array}{l}\text { Observational } \\
\text { (Prospective) }\end{array}$ & 6 months & 203 patients & Online Lexi-Interact \\
\hline [57] & $2009-2010$ & English & All & $\begin{array}{l}\text { Inpatient } \\
\text { (hematology- } \\
\text { oncology ward) }\end{array}$ & Cancer Patients & $\begin{array}{l}\text { Observational } \\
\text { (Retrospective) }\end{array}$ & 12 months & 224 patients & Drug Interaction Facts \\
\hline
\end{tabular}


Table 2 General characteristics of the included studies (Continued)

\begin{tabular}{|c|c|c|c|c|c|c|c|c|}
\hline \multirow[t]{4}{*}{$\begin{array}{l}\text { Range: } \\
1997-2013\end{array}$} & \multirow[t]{4}{*}{$\begin{array}{l}\text { English: } 13 \\
\text { Persian: } 21\end{array}$} & $\begin{array}{l}\text { All Populations: } \\
27\end{array}$ & Outpatient: 19 & Observational: 31 & $\begin{array}{l}\text { Minimum: } \\
1 \text { month }\end{array}$ & $\begin{array}{l}\text { Prescription: } \\
23\end{array}$ & $\begin{array}{l}\text { Prescriptions: } \\
\text { Minimum: } \\
519 \\
\text { Maximum: } \\
44,564,650\end{array}$ & FACT: 20 \\
\hline & & $\begin{array}{l}\text { Elderly: } 3 \\
\text { War-injured: } 2\end{array}$ & Inpatient: 15 & Interventional: 3 & $\begin{array}{l}\text { Maximum: } \\
36 \text { months }\end{array}$ & Patient: 11 & $\begin{array}{l}\text { Patients: } \\
\text { Minimum: } 70\end{array}$ & Others: 9 \\
\hline & & & ICU: 6 & & & & $\begin{array}{l}\text { Maximum: } \\
2041\end{array}$ & \\
\hline & & $\begin{array}{l}\text { Pediatrics: } 1 \\
\text { Adults: } 1\end{array}$ & All Dep.: 9 & & $\begin{array}{l}\text { Mod: } 6 \\
\text { months } \\
(38 \%)\end{array}$ & & & Not Stated: 5 \\
\hline
\end{tabular}


Table 3 Factors associated with incidence of DDls

\begin{tabular}{|c|c|c|}
\hline \multicolumn{2}{|l|}{ Factors } & \multirow{2}{*}{$\begin{array}{l}\text { Description } \\
\text { The DDI incidence was significantly higher among male doctors }[33,46] \text {. }\end{array}$} \\
\hline Physician & Gender & \\
\hline & Age & $\begin{array}{l}\text { Older physicians prescribed medications with more major DDIs than younger physicians (Not statistically } \\
\text { significant) [46]. }\end{array}$ \\
\hline & Specialty & $\begin{array}{l}\text { Major DDIs were higher in the prescriptions of specialist practitioners in comparison to general practitioners } \\
\text { (cardiologists and internists ranked top on the list, while dermatologists ranked the lowest) [50]. }\end{array}$ \\
\hline & & General practitioners had more prescriptions with major DDIs than specialists (statistically significant) [33]. \\
\hline & & $\begin{array}{l}\text { Significant level } 1 \text { DDIs }{ }^{1} \text { were higher in prescriptions of internal specialists and cardiologists than other } \\
\text { practitioners [31]. }\end{array}$ \\
\hline & & $\begin{array}{l}\text { Significant level } 2 \text { DDIs }^{1} \text { were higher in prescriptions of obstetrician and gynecologist than other } \\
\text { practitioners [31]. }\end{array}$ \\
\hline & & Significant level 3 DDls ${ }^{1}$ were higher in prescriptions of general physicians than specialists [31]. \\
\hline & & $\begin{array}{l}\text { General physicians prescribed more medications with major DDIs than specialists (Not statistically } \\
\text { significant) [46]. }\end{array}$ \\
\hline & Number of Prescriptions & $\begin{array}{l}\text { Physicians with } 150 \text { or more prescriptions in one month had more DDIs than the others (statistically } \\
\text { significant) [33]. }\end{array}$ \\
\hline \multirow[t]{10}{*}{ Patient } & Gender & DDls were significantly higher in female patients [53]. \\
\hline & & DDIs were significantly higher in male patients [42]. \\
\hline & Age & Clinically relevant DDls were more common for patients 75 years or above than other patients [51]. \\
\hline & & DDls were significantly higher in patients aged over 60 years than other patients $[42,53,57]$. \\
\hline & Disease & DDls were significantly higher in cardiology patients than other patients [53]. \\
\hline & & DDls were higher in Hematologic cancer patients than patients suffer from other diseases [57]. \\
\hline & & $\begin{array}{l}\text { DDls were higher in patients whose source of cancer was in different specific organs than other } \\
\text { cancer patients [57]. }\end{array}$ \\
\hline & Length of Hospital Stay & DDls were higher in patients with longer hospital stay than other patients $[42,57]$. \\
\hline & Department & DDls occurred in surgery department more than the other departments [36]. \\
\hline & Drug & DDls was significantly higher in patients who have been prescribed digoxin than other patients [53]. \\
\hline
\end{tabular}

${ }^{1}$ Significance rating is based on Drug Interactions Facts ${ }^{T M}$. The factors are related to physicians and patients' characteristics.

\section{Discussion}

This study aimed to provide an overview of the incidence and pattern of DDIs and associated factors in Iran, as an example of a developing country. This is the first review study that summarizes the available evidence of DDIs in Iran.

We identified and described the results of 34 relevant studies addressing the key questions of this review. The overall quality of DDIs studies in Iran was relatively poor, perhaps due to lack of a standard guideline for designing methodology and reporting results of medication error studies. The median incidence of potential DDIs in prescriptions in outpatient settings was $8.5 \%$, while it was $19.2 \%$ in inpatient settings. Patient age was the most reported factor influencing the incidence of DDIs. Only three studies were interventional, and all showed significant reduction in potential DDIs.

Our results show that all DDIs studies in Iran assessed potential DDIs, while no study was performed on actual DDIs. Actual DDIs are interactions that actually lead to adverse clinical events in patients. Espinosa-Bosch et al. found a larger number of studies on potential DDIs than on actual DDIs in developed countries (42 vs. 5 studies) [19]. From eight studies included in the review of DDIs in oncology, six assessed potential DDIs while two reported actual DDIs [21]. Our findings in accordance with those from studies in developed countries confirm that there is little evidence of the incidence of actual DDIs in comparison to potential DDIs in the literature. The reason for this may be that identifying actual DDIs is much more complicated than potential DDIs. The majority of the included studies were retrospective which had used computerized programs to review physicians' orders and prescriptions and to identify potential DDIs. However, to identify actual DDIs, it is required to find the adverse events and confirm that they are a result of simultaneously administering two drugs in the patient regarding his/her condition. The adverse events from DDIs are either not identified or not documented accurately. It should be noted that due to inherent and recall biases and also ethical considerations, the conduction of study designs for assessing actual DDIs may be challenging.

We showed the overall incidence of DDIs in prescriptions in inpatient and outpatient settings reported by 
Table 4 The most frequent major DDIs

\begin{tabular}{|c|c|}
\hline The most frequent major DDIs & References \\
\hline Digoxin + Furosemide & {$[25-27,50,53]$} \\
\hline Captopril + Triamterene-H & {$[38,50]$} \\
\hline Carvedilol + Salbutamol(Albuterol) & {$[56,57]$} \\
\hline Aspirin + Clopidogrel & {$[56]$} \\
\hline Clopidogrel + Omeprazole & {$[56]$} \\
\hline Pantoprazole + Clopidogrel & {$[56]$} \\
\hline Aspirin + Warfarin & {$[56]$} \\
\hline Haloperidol + Propranolol & {$[50]$} \\
\hline Amitriptyline + Clonidine & {$[50]$} \\
\hline Chlorpromazine + Propranolol & {$[50]$} \\
\hline Propranolol + Verapamil & {$[50]$} \\
\hline Amiodaron + Digoxin & {$[50]$} \\
\hline Gemfibrozil + Atorvastatin & {$[50]$} \\
\hline Cyclosporine + Fluconazole & {$[55]$} \\
\hline Cyclosporine + Phenytoin & {$[55]$} \\
\hline Atorvastatin + Fluconazole & {$[55]$} \\
\hline Lovastatin + Gemfibrozil & {$[55]$} \\
\hline Arsenic Trioxide + Fluconazole & {$[55]$} \\
\hline Aspirin + Ibuprofen & {$[32]$} \\
\hline Theophylline + Propranolol & {$[32]$} \\
\hline Pseudoephedrine + Furazolidone & {$[32]$} \\
\hline Dextromethorphan + Furazolidone & [32] \\
\hline Tranylcypromine + Levodopa & {$[29]$} \\
\hline Clomipramine + Furazolidone & {$[29]$} \\
\hline Clonazepam + Olanzapine & [43] \\
\hline Digoxin + Verapamil & {$[46]$} \\
\hline Rifampin + Isoniazid & {$[48]$} \\
\hline Verapamil + Erythromycin & {$[53]$} \\
\hline
\end{tabular}

Iranian studies (inpatient: median $=8.5 \%$, IQR: 8.4-10.1; outpatient: median $=19.2 \%$, IQR: $15.5-22$ ). The high incidence of DDIs may be associated with high number of drugs per prescription. The mean number of drugs per prescription in Iran is relatively high [58]. This mean number for the outpatient setting was 3.16 and 3.05 in 2010 and 2011, respectively, and $17 \%$ and $15 \%$ of these prescriptions involved more than four drugs in those years. No similar review aggregated the reported incidence of DDIs in the general population. The other review studies on DDIs have been conducted on either a specific group of patients, e.g. elderly, hospitalized patients, or specific types of drugs e.g. cardiovascular.

The aggregation and comparison of the results of the included studies showed a wide variability of DDIs incidence estimates in the Iranian healthcare community. Relatively few studies which were performed in the general population in developed countries also showed a wide variability of estimates on incidence of DDIs (i.e. 9.8\% in Finland [59], 18.5\% in Greece [17]). Moreover, a systematic review on incidence of medication errors in Iran showed a wide variability of estimates [60]. Different study methods, various drug interaction databases, diverse study populations, different sample sizes, and some other factors have caused this considerable variability; therefore, direct comparison between the studies is impossible. Maximum incidence of potential DDIs in prescriptions (50\%) was reported in a study which assessed DDIs of cardiovascular drugs in outpatient prescriptions [26]. Similarly, the findings obtained in a study from a developed country showed that $80 \%$ of elderly hospitalized patients with heart diseases were susceptible to DDIs [61]. The high number of prescribed drugs and also frequent prescribing of some drugs with many possible DDIs may cause the high incidence of DDIs in this group of patients. One included study in our review reported the incidence of potential DDIs among cancer patients as $37.5 \%$ [57]. A study conducted in a developed country has shown that $27 \%$ of cancer patients were subject to DDIs [62]. Supporting the results of these studies, a review on DDIs among cancer patients reported that approximately one-third of cancer patients are susceptible to DDIs [21]. High growth in the number of new anti-cancer drugs may be one of the main reasons for this.

Incidence of DDIs may be associated with characteristics of patients, prescribers and pharmacists, or some barriers such as insufficient communication between these groups. Good communication between prescribers and pharmacists is crucial to reduce the risks of DDIs [63]. Among studies conducted in Iran, no study has assessed pharmacists' factors and communication between participants as determinants of DDIs. One review paper specified potential determinants of DDIs associated with pharmacists' characteristics [64]. In that review, the relationship between pharmacists and prescribers, quality of signals from surveillance programs, pharmacists' workload, and also availability, quality, and sensitivity of DDIs softwares have been mentioned as the main potential factors that contribute to the occurrence of DDIs. The Iranian studies showed that having heart disease, being old, and receiving digoxin were the main patient factors associated with high incidence of DDIs. Similarly, the findings from another review on the incidence of DDIs in a developed country highlighted these risk factors [19]. Many studies have emphasized that the high incidence of DDIs in the elderly is due to physiological changes related to age, suffering from multiple diseases, and a high rate of medication use. The results reported by Juurlink et al. [7], which show that digoxin toxicity due to DDIs leads to elderly hospitalization, is in line with the results of the Iranian studies. Concerning prescribers' factors, DDIs were higher in the prescriptions of male prescribers and physicians with greater 
Table 5 The most common drugs contributing to DDIs

\begin{tabular}{|c|c|c|}
\hline Names and classes of drugs & $\begin{array}{l}\text { Percentage of } \\
\text { identified DDIs }\end{array}$ & Reference \\
\hline Beta Blockers & $35.21 \%$ & [26] \\
\hline Inotropic Drugs e.g. Digoxin & $15.94 \%$ & \\
\hline ACEls $^{1}$ e.g. Captopril & $15.35 \%$ & \\
\hline Diuretics e.g. Furosemide & $14.66 \%$ & \\
\hline $\begin{array}{l}\text { Calcium Channel Blockers e.g. } \\
\text { Diltiazem }\end{array}$ & $7.33 \%$ & \\
\hline Nitrate e.g. Nitrocardin & $4.18 \%$ & \\
\hline $\begin{array}{l}\text { Antihyperglycemic Drugs e.g. } \\
\text { Clofibrate }\end{array}$ & $4.09 \%$ & \\
\hline $\begin{array}{l}\text { Antiarrhythmic Drugs e.g. } \\
\text { Amiodarone }\end{array}$ & $2.64 \%$ & \\
\hline Digoxin & $50 \%$ of severe DDls & [27] \\
\hline Gentamicin & $\begin{array}{l}26.5 \% \text { of moderate } \\
\text { DDls }\end{array}$ & \\
\hline Diphenhydramine Compound & $24.85 \%$ & [28] \\
\hline Dextromethorphan-P & $15.38 \%$ & \\
\hline Pseudoephedrine & $11.8 \%$ & \\
\hline Antibiotics & $7.1 \%$ & \\
\hline Tricyclic Antidepressant & $72.7 \%$ & [29] \\
\hline $\mathrm{MAOIs}^{4}$ & $25.2 \%$ & \\
\hline $\mathrm{SRIs}^{3}$ & $2.1 \%$ & \\
\hline Antibiotics & Not specified & [24] \\
\hline Central Nervous System Drugs & Not specified & \\
\hline NSAIDs $^{2}$ & Not specified & \\
\hline Antidepressant & $52 \%$ & {$[40]$} \\
\hline Anti Infectives & $27.5 \%$ & [41] \\
\hline Other Drugs & $21.5 \%$ & \\
\hline Antiarrhythmic & $15.5 \%$ & \\
\hline Antihypertensive & $11.1 \%$ & \\
\hline Anti-diabetic & $5.6 \%$ & \\
\hline Anticoagulant & $5.6 \%$ & \\
\hline Diuretics & $3.7 \%$ & \\
\hline Hormone & $2.5 \%$ & \\
\hline Salicylate & $2.3 \%$ & \\
\hline Anticonvulsant & $1.8 \%$ & \\
\hline Antidepressant & $47.5 \%$ & [43] \\
\hline Belladonna & $4.4 \%$ & [49] \\
\hline Phenytoin Compound & $4.3 \%$ & \\
\hline Cimetidine & $3.8 \%$ & \\
\hline Propranolol Hydrochloride & $3.6 \%$ & \\
\hline Gentamicin & $3.5 \%$ & \\
\hline Acetylsalicylic Acid & $3.5 \%$ & \\
\hline Aluminium MGS & $3.4 \%$ & \\
\hline Theophylline & $3.3 \%$ & \\
\hline Carbamazepine & $2.8 \%$ & \\
\hline
\end{tabular}

Table 5 The most common drugs contributing to DDIs (Continued)

\begin{tabular}{|c|c|c|}
\hline Contraceptive LD & $2.7 \%$ & \\
\hline Digoxin & Not specified & [50] \\
\hline Diuretics & Not specified & \\
\hline HMG CoA Reductase Inhibitors & Not specified & \\
\hline Allopurinol & Not specified & \\
\hline ACEls & Not specified & \\
\hline Warfarin & Not specified & \\
\hline Gemfibrozil & Not specified & \\
\hline Haloperidol & Not specified & \\
\hline Amiodarone & Not specified & \\
\hline Clonidine & Not specified & \\
\hline Cardiovascular Drugs & Not specified & [52] \\
\hline Digoxin & $\begin{array}{l}\text { Most common in } \\
\text { severe DDls }\end{array}$ & [53] \\
\hline ACEls & $\begin{array}{l}\text { Most common in } \\
\text { severe and moderate } \\
\text { DDIs }\end{array}$ & \\
\hline Beta Blockers & $\begin{array}{l}\text { Most common in } \\
\text { moderate DDls }\end{array}$ & \\
\hline Fluoroquinolones & $\begin{array}{l}\text { Most common in } \\
\text { moderate DDls }\end{array}$ & \\
\hline Antacids & $\begin{array}{l}\text { Most common in } \\
\text { moderate DDls }\end{array}$ & \\
\hline Phenytoin & Not specified & {$[54]$} \\
\hline Antimycotics for systemic use ${ }^{5}$ & $31.35 \%$ & [55] \\
\hline Immunosuppressants & $13.51 \%$ & \\
\hline Sulfonamides and Trimethoprim & $9.73 \%$ & \\
\hline Antiepileptics & $8.11 \%$ & \\
\hline Antiemetics and Antinauseants & $7.02 \%$ & \\
\hline Antigout Preparations & $4.05 \%$ & \\
\hline $\begin{array}{l}\text { Corticosteroids for Systemic Use, } \\
\text { Plain }\end{array}$ & $3.78 \%$ & \\
\hline Other Antineoplastic Agents & $2.43 \%$ & \\
\hline Direct Acting Antivirals & $2.43 \%$ & \\
\hline Other Beta-lactam Antibacterials & $2.16 \%$ & \\
\hline
\end{tabular}

Names and classes of drugs which mostly contributed to DDIs and percentage of identified DDIs by the relevant studies are shown.

${ }^{1}$ ACEls: Angiotensin-Converting-Enzyme inhibitors.

${ }^{2}$ NSAIDs: Non-Steroidal Anti-Inflammatory Drugs.

${ }^{3}$ SSRIs: Selective Serotonin Reuptake Inhibitors.

${ }^{4}$ MAOIs: Monoamine Oxidase Inhibitors.

${ }^{5}$ Medication classes categorized by the Anatomical Therapeutic Chemical (ATC) classification system of the World Health Organization.

number of prescriptions in one month. This may be due to the fact that male and busy physicians may less consider the possibility of DDIs during the prescription phase. So far, no study has assessed pharmacological knowledge of prescribers specifically about DDIs.

Drugs most contributing to major DDIs were digoxin, followed by beta blockers, ACEIs, diuretic agents, and 
NSAIDs. Digoxin, ACEIs, and diuretic agents are frequently prescribed to patients with heart diseases; therefore, this may be one of the reasons why DDIs are highly prevalent in these patients. These results are in the same line as two other reviews which mainly included studies from developed countries $[19,20]$.

The included studies in this review have used various DDIs compendia, mostly (59\%) Drug Interaction Facts. Studies have shown that there are discrepancies between DDI compendia $[65,66]$. In addition, other studies showed that the various performance measures used (such as accuracy, sensitivity, and specificity) of multiple DDI identifying software vary [67-69]. Therefore, one should consider these discrepancies in the resources when comparing the result of the DDI related studies. Clinical relevancy of DDIs is another important issue that should be considered when interpreting DDI related study results, as well as in practice.

Despite the high incidence of DDIs in Iran, only three studies implemented interventions to reduce them $[34,35,46]$. Two studies evaluated the effects of educational interventions on reduction of DDIs $[34,46]$ and one study evaluated the effect of audit feedback on the quality of prescriptions [35]. The studies showed significant reduction of DDIs after the interventions. In recent years, computerized systems have been involved in medication error reduction strategies and shown to be effective [70]. Computerized physician order entry systems and drug interaction softwares linked to knowledge bases could detect potential DDIs and alert prescribers to prevent serious outcomes. These systems screen the drug list before finalizing an order. In case of a potential medication error, especially a DDI, alerts are displayed and changes in the prescription can be made. Although numerous studies in different countries mentioned the potential improvement of patient safety by computerized systems, there are no studies published on the evaluation of such systems in Iran.

It should be noted that the present review had several limitations. First, although the comprehensive searches were performed, we may have missed some relevant studies. It may be due to limitations of the Persian search engines. To overcome this limitation, we used several search strategies including searching bibliographies of included studies (snowball method). In addition, we searched Google Scholar using both Persian and English search terms. Second, the methodologies of the included studies in our review were heterogeneous. This made it difficult to aggregate their widely varying results. Therefore, no quantitative meta-analysis has been attempted. Third, we did not include results of the unpublished studies (e.g. dissertations and conference papers) in the review. This may affect our estimations. Finally, some of the included studies in our review had small sample sizes (Table 2) that might have led to bias. These may have limited the generalizability of our results.

Due to the lack of studies addressing actual DDIs among Iranian patients, the incidence of adverse events caused by this type of medication errors remains unknown. It is recommended that future DDIs researches investigate the adverse events of DDIs through closely monitoring the patients who are provided with potentially interacting drugs. The prescribers should be aware of the high incidence of DDIs in their prescriptions. They also need to pay attention to patients who are frequently prescribed potentially interacting drugs (e.g. digoxin, beta blockers, NSAIDs, ACEIs, and diuretic agents). In the absence of studies assessing communication among the drug management team (physician, nurse, and pharmacist), it is suggested that future studies delve into aspects of this communication. Better communication between the team members could lead to a safe pharmacotherapy plan and reduce the risks of adverse events caused by DDIs. In recent years, information technology interventions have been employed to improve medication safety and shown to be effective in reducing the number of potential DDIs. We suggest designing and evaluation of such information technology interventions.

\section{Conclusion}

Although there is a large number of studies on the potential DDIs in Iran, there is still no evidence of the incidence of actual DDIs. The included studies in this review had relatively poor quality and were heterogeneous in their methodologies and reporting. However, almost all studies concluded that the incidence of DDIs in both inpatient and outpatient settings is high. Despite this high incidence, there is a limited number of interventional studies aimed at reducing DDIs incidence. Finally, more extensive research is needed to identify and minimize the factors associated with the incidence of DDIs, and to design and evaluate the effects of interventions especially those that utilize information technology to increase awareness about DDIs and decrease their incidence by the drug management team.

\section{Abbreviations}

DDI: Drug-drug interaction; ADE: Adverse drug event; NSAIDs: Non-steroidal anti-inflammatory drugs; ACEls: Angiotensin-converting-enzyme inhibitors; MAOIs: Monoamine oxidase inhibitors; SSRIs: Selective serotonin reuptake inhibitors; ATC: Anatomical therapeutic chemical classification; IQR: Interquartile range.

\section{Competing interests}

The authors declare that they have no competing interests.

\section{Authors' contributions}

SE and EN conceived the study idea and design. SE, HV, and EN participated in the literature search, inclusion process, and data abstraction. SE, ZhT, and EN participated in the methodological quality assessment of the included studies and interpretation of data. EN drafted the manuscript. All authors 
have been involved in critically revising the manuscript. All authors read and approved the final manuscript.

\section{Acknowledgements}

This study was a part of the first author's PhD thesis which was supported by a grant from Mashhad University of Medical Sciences Research Council.

\section{Author details}

'Student Research Committee, Department of Medical Informatics, Faculty of Medicine, Mashhad University of Medical Sciences, Mashhad, Iran.

${ }^{2}$ Department of Health Information Management/Technology, School of Allied Health Professions, Kashan University of Medical Sciences, Kashan, Iran. ${ }^{3}$ Neurogenic Inflammation Research Center, Faculty of Medicine, Mashhad University of Medical Sciences, Mashhad, Iran. ${ }^{4}$ Targeted Drug Delivery Research Center, School of Pharmacy, Mashhad University of Medical Sciences, Mashhad, Iran. ${ }^{5}$ Pharmaceutical Research Center, School of Pharmacy, Mashhad University of Medical Sciences, Mashhad, Iran. ${ }^{6}$ Department of Medical Informatics, Faculty of Medicine, Mashhad University of Medical Sciences, Mashhad, Iran. ${ }^{7}$ Department of Medical Informatics, Academic Medical Center, University of Amsterdam, Amsterdam, The Netherlands.

Received: 13 April 2014 Accepted: 20 June 2014 Published: 25 June 2014

\section{References}

1. Gurwitz JH, Field TS, Harrold LR, Rothschild J, Debellis K, Seger AC, Cadoret C, Fish LS, Garber L, Kelleher M, Bates DW: Incidence and preventability of adverse drug events among older persons in the ambulatory setting. JAMA 2003, 289:1107-1116.

2. Thomsen LA, Winterstein AG, Sondergaard B, Haugbolle LS, Melander A: Systematic review of the incidence and characteristics of preventable adverse drug events in ambulatory care. Ann Pharmacother 2007, 41:1411-1426.

3. Tache SV, Sonnichsen A, Ashcroft DM: Prevalence of adverse drug events in ambulatory care: a systematic review. Ann Pharmacother 2011, 45:977-989.

4. Lazarou J, Pomeranz BH, Corey PN: Incidence of adverse drug reactions in hospitalized patients: a meta-analysis of prospective studies. JAMA 1998, 279:1200-1205.

5. Field TS, Gilman BH, Subramanian S, Fuller JC, Bates DW, Gurwitz JH: The costs associated with adverse drug events among older adults in the ambulatory setting. Med Care 2005, 43:1171-1176.

6. Hug BL, Keohane C, Seger DL, Yoon C, Bates DW: The costs of adverse drug events in community hospitals. It Comm J Qual Patient Saf 2012, 38:120-126.

7. Juurlink DN, Mamdani M, Kopp A, Laupacis A, Redelmeier DA: Drug-drug interactions among elderly patients hospitalized for drug toxicity. JAMA 2003, 289:1652-1658.

8. Astrand E, Astrand B, Antonov K, Petersson G: Potential drug interactions during a three-decade study period: a cross-sectional study of a prescription register. Eur J Clin Pharmacol 2007, 63:851-859.

9. Jankel CA, Fitterman LK: Epidemiology of drug-drug interactions as a cause of hospital admissions. Drug Saf 1993, 9:51-59.

10. McDonnell PJ, Jacobs MR: Hospital admissions resulting from preventable adverse drug reactions. Ann Pharmacother 2002, 36:1331-1336.

11. Peyriere H, Cassan S, Floutard E, Riviere S, Blayac JP, Hillaire-Buys D, Le Quellec A, Hansel S: Adverse drug events associated with hospital admission. Ann Pharmacother 2003, 37:5-11.

12. Glintborg B, Andersen SE, Dalhoff K: Drug-drug interactions among recently hospitalised patients-frequent but mostly clinically insignificant. Eur J Clin Pharmacol 2005, 61:675-681.

13. Askari M, Eslami S, Louws M, Dongelmans D, Wierenga P, Kuiper R, Abu-Hanna A: Relevance of drug-drug interaction in the ICU - perceptions of intensivists and pharmacists. Stud Health Technol Inform 2012, 180:716-720.

14. Ko Y, Malone DC, Skrepnek GH, Armstrong EP, Murphy JE, Abarca J, Rehfeld RA, Reel SJ, Woosley RL: Prescribers' knowledge of and sources of information for potential drug-drug interactions: a postal survey of US prescribers. Drug Saf 2008, 31:525-536.

15. Heininger-Rothbucher D, Bischinger S, Ulmer H, Pechlaner C, Speer G, Wiedermann CJ: Incidence and risk of potential adverse drug interactions in the emergency room. Resuscitation 2001, 49:283-288.
16. Straubhaar B, Krahenbuhl S, Schlienger RG: The prevalence of potential drug-drug interactions in patients with heart failure at hospital discharge. Drug Saf 2006, 29:79-90

17. Chatsisvili A, Sapounidis I, Pavlidou G, Zoumpouridou E, Karakousis VA, Spanakis M, Teperikidis L, Niopas I: Potential drug-drug interactions in prescriptions dispensed in community pharmacies in Greece. Pharm World Sci 2010, 32:187-193.

18. Marzolini C, Elzi L, Gibbons S, Weber R, Fux C, Furrer H, Chave JP, Cavassini M, Bernasconi E, Calmy A, Vernazza P, Khoo S, Ledergerber B, Back D, Battegay M: Prevalence of comedications and effect of potential drug-drug interactions in the Swiss HIV Cohort Study. Antivir Ther 2010, 15:413-423.

19. Espinosa-Bosch M, Santos-Ramos B, Gil-Navarro MV, Santos-Rubio MD, Marin-Gil R, Villacorta-Linaza P: Prevalence of drug interactions in hospital healthcare. Int J Clin Pharm 2012, 34:807-817.

20. Hines LE, Murphy JE: Potentially harmful drug-drug interactions in the elderly: a review. Am J Geriatr Pharmacother 2011, 9:364-377.

21. Riechelmann RP, Del Giglio A: Drug interactions in oncology: how common are they? Ann Oncol 2009, 20:1907-1912.

22. Alsulami Z, Conroy S, Choonara I: Medication errors in the Middle East countries: a systematic review of the literature. Eur J Clin Pharmacol 2013, 69:995-1008.

23. Ghaleb MA, Barber N, Franklin BD, Yeung WW, Khaki ZF, Wong IC: Systematic review of medication errors in pediatric patients. Ann Pharmacother 2006, 40:1766-1776.

24. Cheraghali AAM, Ali Dadi A, Panahi Y: Evaluation of physicians prescriptions in hospitals affiliated to a medical science University in Tehran. Teb Va Tazkieh 2002, 1:30-36.

25. Rafeian M: Drug interactions in internal and surgical wards of Kashani Hospital, Shahrekord, 1997. Tehran Univ Med J 2001, 59:86-91.

26. Morteza-Semnani K, Saeedi M, Gharipour O: Evaluation of cardiovascular drugs interactions in insured prescriptions in Sari during the years 2000-2001. J Mazandaran Univ Med Sci 2001, 11:37-45.

27. Sobhani A, Shodjai H: Prevalence of polypharmacy and correlations with sex, age and drug regimen in insurance prescription. J Guilan Univ Med Sci 2001, 10:90-96.

28. Nabavizadeh S, Khoshnevisan F: Drug interactions in prescriptions of general practitioners in Yasuj city. J Armaghan Danesh 2003, 7:53-59.

29. Morteza-Semnani K, Saeidi M, Isazade Mashinchi M: Evaluation of anti-depressant drugs interactions in insured prescriptions in Anzali in 1379. J Guilan Univ Med Sci 2002, 11:26-33.

30. Ebrahim Zadeh MA, Gholami K, Gharanjik U, Javadian PSM: Evaluation of Drug Interactions of Non-Steroidal Anti-Inflammatory Drugs (Nsaids) in Sari insured prescriptions during 1999-2001. Razi J Med Sci 2003, 10:489-495.

31. Asgarirad H, Pourmorad F, Akbari K: Pattern of prescription and drug interaction in prescriptions of Nowshahr and Chalous physicians (2001). Med J Hormozgan Univ 2004, 7:167-172.

32. Rashidi K, Senobar Tahaee SN: Assessment of drug interactions in medical insurance prescriptions in Kurdistan province in 2000. Sci J Kurdistan Univ Med Sci 2005, 10:78-84.

33. Khouri V, Semnani S, Roushandel G: Frequency distribution of drug interactions and some of related factors in prescriptions. Med J Tabriz Univ Med Sci Health Serv 2006, 27:29-32.

34. Ghorbani M, Hosseini M, KHouri V: Evaluation of face to face training effects on reduction of drug interactions on insured prescription of physicians. Med Sci I Islamic Azad Univ Tehran Med Branch 2007, 17:171-175.

35. Zare N, Razmjoo M, Ghaeminia M, Zeighami B, Aghamaleki Z: Effectiveness of the feedback and recalling education on quality of prescription by general practitioners in Shiraz. Zahedan J Res Med Sci 2008, 9:255-261.

36. Shayan Z, Shayan F: Pattern of drug prescription in clinical ward of Motahari and Peimanie hospital in Khordad 1385. J Jahrom Univ Med Sci 2007, 5:44-50.

37. Valizadeh F, Ghasemi S, Nagafi S, Delfan B, Mohsenzadeh A: Errors in medication orders and the nursing Staff's reports in medical notes of children. Iran J Pediatr 2008, 18:33-40.

38. Dolatabadi M, Jalili Rasti H: Patterns of Physicians' drug prescription in Sabzevar Iran (2008). J Sabzevar Univ Med Sci 2009, 16:161-166.

39. Nezafati S, Maleki N, Golikhani R: Quality assessment of health services insurance prescriptions among the dentists of Tabriz city in 2005-2006. Med J Tabriz Univ Med Sci 2009, 31:101-104.

40. Gorji A, Gharakhani M, Razeghi Jahromi S, Sadeghian H, Faghihzadeh S, Kazemi H, Arabkheradmand J, Koulivand P, Bayan L: Multiple drug 
interactions in war-injured veterans. Iran J War Public Health 2010, 2:23-28.

41. Alizadeh A, Rostamian A, Saeedpour K, Hemmati M, Khorasani Z, Mohagheghi M, Khatami Moghaddam M, Mousavi M: Drug interactions frequency in the bedridden patients in three hospitals of Tehran city. Modern Care J 2011, 7:22-27.

42. Rafieii H, Arab M, Ranjbar H, Arab N, Sepehri G, Amiri M: The prevalence of potential drug interactions in Intensive Care Units. Iran J Crit Care Nurs 2012, 4:191-196.

43. Esteghamat S, Esteghamat S, Bastani F, Kazemi H, Koulivand P, Bayan L, Gorji A: Potential drug interactions in war-injured veterans with psychaitric disorders. Iran J War Public Health 2012, 4:24-31.

44. Rafiei $H$ : The prevalence of potential drug interactions among critically il elderly patients in the Intensive Care Unit (ICU). Iran J Ageing 2012, 6:14-19.

45. Hajebi G, Mortazavi S: An Investigation of Drug Interactions in Hospital Pharmacy Prescriptions. Iran J Pharm Res 2002, 1:15-19.

46. Khouri $V$, Abbasi $A$, Besharat $S$ : The effect of active training in reducing severe drug interactions. Iran J Med Edu 2004, 6:107-112.

47. Azoulay L, Zargarzadeh A, Salahshouri Z, Oraichi D, Berard A: Inappropriate medication prescribing in community-dwelling elderly people living in Iran. Eur J Clin Pharmacol 2005, 61:913-919.

48. Abbasi Nazari M, Khanzadeh Moqhadam N: Evaluation of Pharmacokinetic Drug Interactions in Prescriptions of Intensive Care Unit (ICU) in a Teaching Hospital. Iran J Pharm Res 2006, 5:215-218.

49. Taheri E, Afshari R, Nazemian L: Population-based severity, onset and type of drug-drug interactions in prescriptions. Methods Find Exp Clin Pharmacol 2010, 32:237-242.

50. Ahmadizar F, Soleymani F, Abdollahi M: Study of drug-drug interactions in prescriptions of general practitioners and specialists in Iran 2007-2009. Iran J Pharm Res 2011, 10:921-931.

51. Ghadimi H, Esmaily HM, Wahlstrom R: General practitioners' prescribing patterns for the elderly in a province of Iran. Pharmacoepidemiol Drug Saf 2011, 20:482-487.

52. Mortazavi S, Hajebi G: An investigation on the nature and extent of occurrence of errors of commission in hospital prescriptions. Iran J Pharm Res 2003, 2:83-87.

53. Sepehri G, Khazaelli P, Dahooie FA, Sepehri E, Dehghani MR: Prevalence of potential drug interactions in an Iranian general hospital. Indian J Pharm Sci 2012, 74:75-79.

54. Rafiei $H$, Esmaeli Abdar M, Amiri M, Ahmadinejad M: The study of harmful and beneficial drug interactions in intensive care, Kerman, Iran. J Intensive Care Society 2013, 14:155-158.

55. Hadjibabaie M, Badri S, Ataei S, Moslehi AH, Karimzadeh I, Ghavamzadeh A: Potential drug-drug interactions at a referral hematology-oncology ward in Iran: a cross-sectional study. Cancer Chemother Pharmacol 2013, 71:1619-1627

56. Haji Aghajani M, Sistanizad M, Abbasinazari M, Abiar Ghamsari M, Ayazkhoo L Safi O, Kazemi K, Kouchek M: Potential drug-drug interactions in post-CCU of a teaching hospital. Iran J Pharm Res 2013, 12:243-248.

57. Tavakoli Ardakani M, Kazemian K, Salamzadeh J, Mehdizadeh M: Potential of drug interactions among hospitalized cancer patients in a developing country. Iran J Pharm Res 2013, 12:175-182.

58. National indicators for drug prescription in Iran. http://fdo.behdasht.gov. ir/index.aspx?siteid=114\&pageid=45999.

59. Heikkila T, Lekander T, Raunio H: Use of an online surveillance system for screening drug interactions in prescriptions in community pharmacies. Eur J Clin Pharmacol 2006, 62:661-665.

60. Mansouri A, Ahmadvand A, Hadjibabaie M, Kargar M, Javadi M, Gholami K: Types and severity of medication errors in Iran; a review of the current literature. Daru 2013, 21:49.

61. Kohler Gl, Bode-Boger SM, Busse R, Hoopmann M, Welte T, Boger RH: Drug-drug interactions in medical patients: effects of in-hospital treatment and relation to multiple drug use. Int J Clin Pharmacol Ther 2000, 38:504-513.

62. Sokol KC, Knudsen JF, Li MM: Polypharmacy in older oncology patients and the need for an interdisciplinary approach to side-effect management. J Clin Pharm Ther 2007, 32:169-175.

63. Mallet $L$, Spinewine A, Huang A: The challenge of managing drug interactions in elderly people. Lancet 2007, 370:185-191.

64. Becker ML, Kallewaard M, Caspers PW, Schalekamp T, Stricker BH: Potential determinants of drug-drug interaction associated dispensing in community pharmacies. Drug Saf 2005, 28:371-378.
65. Fulda TR, Valuck RJ, Zanden JV, Parker S, Byrns PJ, The USPDURAP: Disagreement among drug compendia on inclusion and ratings of drug-drug interactions. Curr Ther Res 2000, 61:540-548.

66. Vitry Al: Comparative assessment of four drug interaction compendia. Br J Clin Pharmacol 2007, 63:709-714.

67. Barrons R: Evaluation of personal digital assistant software for drug interactions. Am J Health Syst Pharm 2004, 61:380-385.

68. Reis AM, Cassiani SH: Evaluation of three brands of drug interaction software for use in intensive care units. Pharm World Sci 2010, 32:822-828.

69. Vonbach P, Dubied A, Krahenbuhl S, Beer JH: Evaluation of frequently used drug interaction screening programs. Pharm World Sci 2008, 30:367-374.

70. Eslami S, de Keizer NF, Abu-Hanna A: The impact of computerized physician medication order entry in hospitalized patients-a systematic review. Int J Med Inform 2008, 77:365-376.

doi:10.1186/2008-2231-22-52

Cite this article as: Nabovati et al:: Drug-drug interactions in inpatient and outpatient settings in Iran: a systematic review of the literature. DARU Journal of Pharmaceutical Sciences 2014 22:52.

\section{Submit your next manuscript to BioMed Central and take full advantage of:}

- Convenient online submission

- Thorough peer review

- No space constraints or color figure charges

- Immediate publication on acceptance

- Inclusion in PubMed, CAS, Scopus and Google Scholar

- Research which is freely available for redistribution 